\title{
Student perceptions of veterinary anatomy practical classes: a longitudinal study
}

Erica Gummery

erica.gummery@nottingham.ac.uk

Teaching Associate in Veterinary Anatomy

School of Veterinary Medicine and Science

University of Nottingham

Sutton Bonington Campus

Loughborough

LE12 5RD

Kate A Cobb

katy.cobb@nottingham.ac.uk

BVetMed, PGCE, MMedSci, PhD, MRCVS

Lecturer in Teaching Learning and Assessment

School of Veterinary Medicine and Science

University of Nottingham

Sutton Bonington Campus

Loughborough

LE12 5RD

Liz H Mossop

liz.mossop@nottingham.ac.uk

BVM\&S, MMedSci (Clin Ed), PhD, MAcadMEd, MRCVS

Associate Professor of Veterinary Education

School of Veterinary Medicine and Science

University of Nottingham

Sutton Bonington Campus

Loughborough

LE12 5RD

Malcolm A Cobb

malcolm.cobb@nottingham.ac.uk.

MA, VetMB, DVC, PhD, MBA, FHEA, MRCVS

Professor of Comparative Veterinary Medicine - Deputy Head of School - Divisional Head

of Medicine, Faculty of Medicine \& Health Sciences

School of Veterinary Medicine and Science

University of Nottingham

Sutton Bonington Campus

Loughborough

LE12 5RD 


\section{Abstract}

Using cadaveric material to teach veterinary students poses many challenges. However, little research exists on the contribution of this traditional approach to student learning. This longitudinal study aimed to investigate student perceptions of cadaver-based anatomy classes in a vertically integrated veterinary curriculum at The University of Nottingham's School of Veterinary Medicine and Science. Likert scale statements and free text boxes were used in a questionnaire distributed to second year veterinary students (response rate $59 \%, n=61 / 103$ ). The same questionnaire was subsequently distributed to the same cohort two years later, in the students' fourth year of study (response rate $68 \%, n=67 / 98$ ). Students agreed that cadaver-based activities aid their learning and they particularly value the opportunities to develop practical skills alongside learning anatomy. There are few changes in perception as undergraduates progress to clinical years of teaching. Students perceive anatomy to be important, and feel that their learning has prepared them for clinical placements. This study emphasises the importance of the effective use of cadaveric materials in the teaching of anatomy and in particular the use of clinical skills to enhance the anatomy curriculum.

Key words: anatomy classes, cadaver teaching, student perception, dissection, prosections, clinical skills

\section{Introduction}

Anatomy education has become an area of much discussion over recent years within medical education literature, with concerns raised over a reduction in time allocated to anatomy teaching and thus graduates' knowledge in the subject. ${ }^{[1-3]}$ Furthermore, ways in which cadaveric material is most effectively utilised in a clinical curriculum remains under debate. ${ }^{[4-8]}$ Teaching anatomy with cadavers poses particular challenges around the control of infectious agents and exposure to chemical fixatives, problems with sourcing cadaver material and the expense of collection and storage of specimens, as well as the ethical questions raised by the use of cadaveric material in teaching. Add to these issues the demands on staff and curriculum time and there is clear cause to investigate the educational value of these teaching sessions. Nevertheless, the matter has received little attention in the context of veterinary education and a search of electronic databases OVID Medline and CAB abstracts returned a limited number of empirical studies on the topic.

Despite recent moves towards student centred learning, teaching anatomy can entail conveying a large volume of detailed factual information, perceived by the student to be learned by rote and then reproduced verbatim for the purpose of assessment. Practical classes provide opportunity for students to 'experience' anatomy; to take the body apart and understand for themselves the 3 dimensional relationships of structures. Maximising the potential of these learning opportunities is the objective of many educators, ${ }^{[9]}$ and whilst there is much debate over the most effective method of teaching anatomy, practical classes remain a key component in human and veterinary anatomy teaching. [10-12]

Traditional methods of practical teaching in anatomy include the dissection of cadaveric specimens by groups of students and demonstration of prosections. Dissection is seen by many as a key tool in teaching anatomy ${ }^{[6]}$ and is valued for fostering others skills such as teamwork, time management, independent learning and manual skills. ${ }^{[13]}$ The demonstration of pre-dissected specimens is appreciated as a more efficient way of delivering anatomical information, by educators and by students ${ }^{[14]}$ and studies have shown the method to be at least as effective as students carrying out dissection for themselves. ${ }^{[15,16]}$ Some educators have removed cadavers from the anatomy curriculum entirely, arguing that the use of cadavers does not provide an authentic experience representative of clinical practice. [17] There are however, concerns about the objectivity of research into teaching methods using cadavers, as many of these studies are carried out by anatomists or by teachers implementing new course designs. $[9,18]$ 
Using clinical skills to reinforce anatomy teaching in traditionally pre-clinical classes is less well researched, possibly due to difficulties in obtaining human cadaveric material. However, opportunities to integrate some aspects of clinical teaching with first and second year anatomy teaching have been introduced successfully within the medical curriculum. Brown et al, ${ }^{[19]}$ measured first year medical student perceptions of the use of ultrasound in anatomy teaching and found that students overwhelmingly agreed that it had been beneficial in their learning, and the experience had increased their confidence and knowledge of anatomy. Interpretation of the images was also assessed through the questionnaire and ninety-eight percent of students identified the structures correctly, demonstrating an understanding of the anatomical structures shown.

Moreover, Ivanusic et al ${ }^{[20]}$ found that students valued the clinical relevance of using ultrasonography in their study of perceptions of undergraduate students at the University of Melbourne. Similarly, a survey administered to first year medical students following a demonstration of laparoscopic anatomy of the abdomen found that students perceived the session to have enhanced their learning and improved interest in the topic. [21]

Since the publication of Tomorrow's Doctors ${ }^{[22]}$ which called for a reduction in factual knowledge in the medical curriculum and a greater emphasis on outcomes-based education, there has been increasing concern about the level of anatomical knowledge of students taught through modern clinically integrated curricula. ${ }^{[23,24]}$ A study carried out by Waterston and Stewart ${ }^{[1]}$ highlighted concerns amongst clinicians about the anatomical knowledge of new medical school graduates, and an investigation into perceptions of newly qualified doctors from the University of Nottingham Medical School performed by Fitzgerald, ${ }^{[2]}$ found a divide in opinion. Results of this study showed $53.8 \%$ of respondents believed they were taught sufficient anatomy at medical school, and $44.3 \%$ believed the anatomy they were taught was not sufficient. These studies suggest that current anatomy curricula are not meeting the outcomes required by the medical profession.

Whilst valuable information can be gleaned from medical education studies, there are important distinctions to be made between the educational processes and outcomes of medical and veterinary curricula. Graduates of human medicine enter into a supervised post-graduation career structure, whereas no such period of additional supervised training is required in the field of veterinary medicine. This need for veterinary graduates to be proficient in clinical techniques as they relate to the Day One Competences defined by the Royal College of Veterinary Surgeons ${ }^{[25]}$ augments the impact of such teaching at vet school. Although a number of authors have reported the need to modernise veterinary gross anatomy curricula ${ }^{[26-28]}$, there is a dearth of literature on the standard of anatomical knowledge and the educational impact of anatomical education amongst veterinary graduates and students. The introduction of new technologies has facilitated the development of tools to aid in veterinary anatomy teaching ${ }^{[29,30]}$ and the impact of educational tools such as plastination and surface anatomy learning aids has been investigated and found to support traditional teaching methods. ${ }^{[31,32]}$ However, there is little empirical data on the continuing impact of teaching practises in anatomy. This longitudinal study investigates the attitudes and opinions of anatomy teaching as students progress through the veterinary course from pre-clinical to clinical teaching.

The School of Veterinary Medicine and Science at the University of Nottingham (SVMS) employs a systems-based spiral curriculum, as described by Harden. ${ }^{[33]}$ This curriculum design provides vertical integration of anatomy through the introduction of clinical skills and concepts in the first term of the course. Anatomy teaching is integrated into systems-based modules and delivered through lectures, student directed group work, and practical classes. Each module is delivered as a veterinary science subject in the first two years of the course and again as a clinical subject during year three or four. Assessment methods include online written papers, practical and portfolio assessments 
intended to evaluate achievement of course learning outcomes. The practical classes at SVMS are designed to incorporate live animal examination sessions, cadaver activities, laboratory and clinical skills and these sessions are run from the first term of the course through to the last term of year 4 . Classes involving the use of cadaver materials are the focus of this research.

Three main teaching methods using cadaver materials are employed in the delivery of anatomy at SVMS; dissection, prosections and practising clinical techniques. Dissection involves groups of 4 students dissecting a mixed-breed, preserved dog cadaver. The cadavers are allocated to an individual group of students and used throughout the academic year as different modules are studied. Task sheets are provided including instructions and structures to be identified during each session. Prosections, or predissected specimens are employed to demonstrate key anatomical features. Specimens are fresh or preserved cadavers or part cadavers and are typically demonstrated by a member of teaching staff to groups of $8-20$ students. Practising clinical techniques describes performing skills such as endoscopy of the nasal cavities of the horse, or ultrasound, nerve block or joint aspiration of cadaver limbs. These procedures are used to reinforce and apply anatomical knowledge. Timetabling of these sessions is such that all students should be able to attempt the skills presented. Plastinated or freeze-dried specimens and models are employed to supplement all three methods of teaching delivery.

The aims of this study are to investigate the following:

1) How do students perceive methods of teaching with cadavers?

2) How do these perceptions change through the course?

3) Do students feel their anatomical knowledge is sufficient for clinical placements?

A greater understanding of student perceptions of learning anatomy will enable educators to evaluate the curriculum and to utilise valuable time and materials to most effectively teach anatomy alongside other skills and values pertinent to a career in veterinary medicine.

\section{Methods}

\section{Survey design}

A questionnaire was designed to measure the student perceptions of each of the three techniques used in cadaver teaching: dissection, prosection and practising clinical skills. The questionnaire comprised thirteen statements, grouped according to the teaching and learning themes of gaining anatomical knowledge, the application of anatomical knowledge, enjoyment, assessment, and the learning process. Students were asked the extent to which they agreed with each statement ( $1=$ strongly agree, $5=$ strongly disagree) in relation to each teaching technique. Free text boxes invited further comments throughout the survey. The survey was reviewed and piloted for clarity with third and fifth year students.

The paper-based questionnaire was distributed to the 2010 cohort of the 5-year full time BVMBVS course at the University of Nottingham during a practical session in the spring term of year 2, at which time students had completed all the systems-based veterinary science modules. The survey was then redistributed two years later to the same cohort during a practical session in the spring term of their fourth year of study, just prior to entering into their final year of supervised clinical practice-based learning and thus they had completed all modules of formal study. The second administration of the survey required students to answer the same statements retrospectively and also contained a further 8 statements in which students were asked to express agreement to relating to clinical studies and post-graduation expectations. Questions were chosen to reflect issues in the current literature and the objectives of the SVMS curriculum. A full questionnaire as administered to year 4 participants is included as appendix 1 . 
Ethical approval for the study was granted by the University of Nottingham School of Veterinary Medicine and Science ethical review committee according to the British Educational Research Association (BERA) guidelines, approval number 461111103. Participation in the study was not mandatory and participants received information sheets regarding data handling and withdrawal from the study. All data were anonymised, with questionnaires from the two different administrations linked by an ID number.

\section{Data Analysis}

Individual Likert item scores were summed according to the aforementioned learning themes and Cronbach's co-efficient alpha was used to assess the homogeneity of items within the domains. When graphically represented, agreement to a Likert statement was taken as 'agree' and 'strongly agree' responses. Reverse scoring of the negatively phrased question was used in reporting relative frequencies.

Data were entered into the statistical package SPSS 21 and as data were considered as non-normally distributed, non-parametric Friedman tests were carried out for repeated measures of the three methods of delivery; dissection, prosection and clinical skills. Differences between responses of the first and second administration of the survey were measured using Wilcoxon signed rank tests. Significance for these tests was defined as $\mathrm{P}<0.05$.

Analysis of the free text responses was carried out using a thematic approach, as described by Braun and Clarke. ${ }^{[34]}$ Coding was carried out manually using an inductive approach and codes were combined to form overarching themes. The data were first analysed by two researchers independently before a process of comparison and review, as described by Patton. ${ }^{[35]}$ A theme was defined as capturing an important element in the data rather than by number of responses pertaining to it.

\section{Results}

\section{Response rate}

A total of 61 surveys were returned from a cohort of 103 second year students upon the first administration (59\%). The second administration two years later returned 67 surveys from a cohort of $98(68 \%)$. Only students present for both administrations of the survey were included for paired comparison, resulting in a total of 40 surveys $(43 \%)$.

\section{Reliability}

Cronbach's alpha values for Likert items within a domain are shown in table 1

\section{(Place Table 1 here)}

\section{Perceptions of second year students}

Students reported a high level of agreement to all but the negatively phrased question. Dissection, prosection and practising techniques all scored highly as teaching methods. Responses and mean scores are shown in table 2.

\section{(Place Table 2 here)}

Practising clinical techniques was more highly rated than dissection or prosection in all teaching and learning themes. Further investigation using Friedman's ANOVA found significant differences between the perception of teaching modalities in the areas of application $\left(X^{2}=21.44, p<.001\right)$, enjoyment $\left(X^{2}=31.66, p<.001\right)$, and learning $\left(X^{2}=21.44, p<.001\right)$. These results are shown in table 3 .

(Place Table 3 here) 
Changes in perceptions between years 2 and 4

Perceptions of dissecting specimens, the demonstration of prosection and practising clinical techniques remain positive throughout the course with little change reflected in the responses of the students. Figure 1 compares the responses of students in year 2 and year 4 . Statistical analysis of the responses showed a significant decrease in positive responses for dissection $(Z=-2.43, p=.015)$ and prosection $(Z=-3.42, p=.001)$ in the application of knowledge. Similarly, for dissection $(Z=-2.09, p=.036)$ and prosection $(Z=-2.45, p=.014)$ in assessment of knowledge. In these areas students placed more value on these methods of learning in year 2 than they did in year 4 of the course. Practising clinical techniques however was perceived to be equally valuable at the time of teaching and retrospectively, with no significant differences found between the two administrations of the survey.

(Insert Figure 1 here)

\section{Analysis of free text responses}

Four main themes were identified from the initial codes assigned to the free text responses from year 2 students. A further two themes were identified following the analysis of the year 4 responses: relevance and transition to clinical studies. Table 4 provides the main themes and example comments.

(Place table 4 here)

\section{Year 4 specific questions}

Responses to questions about clinical studies are shown in figure 2. Every one of the students surveyed believed anatomy to be an important part of the veterinary curriculum with $78 \%$ of students strongly agreeing and $22 \%$ agreeing to the statement. The students largely disagreed that anatomical knowledge was not required for fourth year studies and reported finding their learned knowledge useful for clinical extramural placements. However, $66 \%$ of students reported to have forgotten most of the anatomical knowledge they had learned in first and second year by the time they reached year 4 of the course, and $51 \%$ of students believe it is not re-visited in fourth year.

Student responses indicate a belief that good anatomical knowledge is important in practice, with $75 \%$ of responses strongly agreeing to the statement, and $24 \%$ agreeing. However, $82 \%$ of those surveyed expect to look up anatomical information as and when it is needed in practice, as is demonstrated by figure 3 .

\section{(Insert Figure 2 here)}

(Insert Figure 3 here)

\section{Discussion}

This study has demonstrated that students value practical learning experiences in both pre-clinical and clinical stages of the veterinary course. Furthermore, embedding clinical skills alongside more traditional teaching practises within the dissection laboratory has proved enjoyable and motivating for this group of students. There are few changes in perception as students progress through the course to clinical teaching, with the opportunity to develop clinical skills in conjunction with learning anatomy highly valued by students in year 4 of the course.

Dissection, prosection and practising clinical techniques as teaching methods in the dissection laboratory are all perceived to have a positive impact on learning. Students enjoyed practising clinical techniques, a finding that has been reported in previous 
studies in human anatomy teaching. ${ }^{[36,37]}$ In this study of students at SVMS, the opportunity to practise clinical skills was also appreciated for the relevance to the role of a veterinarian and was found to be the most motivating of learning methods. Motivation to learn and participate in a task is known to positively correlate with deep learning approaches, $[38,39]$ and linking anatomical topics to clinical aspects of the course has been found to enhance learning and willingness to learn. ${ }^{[40]}$ As such it is important we develop interest through promoting the relevance of anatomical facts in such a way that nurtures the intrinsic motivation of our undergraduate students. There are long standing concerns however, regarding the cognitive load imposed on learners. [41-43] This is increased by introducing teaching methods that pose additional demands on the learner, for example skills in image acquisition and interpretation in the case of ultrasound. However, whilst this has been found to be an issue in physical examination, it was concluded that learners were able to manage the cognitive load introduced by ultrasonography in anatomy teaching situations. ${ }^{44]}$ There were no comments alluding to such struggles returned from students in this study, although it could be argued they are simply unaware of any additional cognitive demands due to the early introduction of these learning methods and thus they have no basis for comparison.

Fourth year students felt that dissection and prosection were less applicable to their career than it was perceived to be in second year, and this supports the findings of a longitudinal study of veterinary students carried out by Heath et al. ${ }^{[45]}$ In this Australian study, $92 \%$ of first year respondents felt that anatomy was extremely relevant to their veterinary training. However, by fifth year and second year of work post-graduation, there were discrepancies between the perception of what was delivered and what should be delivered. Participants of the survey believed more emphasis should have been placed on the skills, knowledge and techniques required for the practice of veterinary science and that there should be less emphasis placed on the basic sciences. However, this study was carried out a number of years ago, and before a review of the curriculum in question. Also of note is that whilst anatomy is generally considered a basic science, Heath's report does not define the term and the study does not investigate perceptions of anatomy education specifically. It does however illustrate how perception can change with students' experiences. It may be the case that a vertically integrated curriculum that places more emphasis on skills and techniques would be perceived as more valuable by fifth year students and graduates.

363

364

365

The study design reported in this manuscript did not invite students to select one particular method over another, and as such it should not be extrapolated that scores would be apportioned similarly without the context of the other teaching modalities. However, practising clinical techniques remains to be a highly valued teaching modality of fourth year students at SVMS. In particular, students cite the relevance of the method of learning to their clinical studies and to clinical placements as having a positive impact. This supports a study of Dutch medical students which found the prime motivating factor to study anatomy is clinical exposure, i.e. conveying the knowledge in context. [46] Context in learning has been found to improve knowledge retention and recall, ${ }^{[47]}$ and is more likely to encourage a deep approach to learning. ${ }^{[48,49]}$ A vertically integrated curriculum facilitates this learning through providing opportunities for contextual learning, as well as promoting repetition of subject matter and increasing time on task. However, the results of this study of SVMS students indicate that they would like more time dedicated to anatomy teaching in fourth year. A review of medical education literature found that it is often the case with vertically integrated curricula that the integration is unidirectional, that is to say that whilst clinical components are introduced in the early years of the course, it is perceived to be far less common for the basic sciences to be included in the clinical years of the curriculum, thus leading to a net loss of teaching time for anatomy. ${ }^{[24]}$ It is important to consider then, that if there is not the time in the clinical curriculum to formally deliver anatomy, that we allow for self-study time for students to re-visit anatomy teaching and that we signpost important anatomical concepts effectively. Similarly, we should be arming students with the life- 
long learning skills that enable students to recognise gaps in their knowledge and source and critically review information. This is particularly pertinent as $82 \%$ of students surveyed for this study expect to look up anatomical information when they need it in practice. Some year 4 students recognised retrospectively their own focus on processes and assessment in pre-clinical years, demonstrating reflective skills that will be invaluable to them as life-long learners. ${ }^{[50]}$ However, they also reported a preference for teacher-led approaches to teaching, supporting the views of Hall et al ${ }^{[51]}$ that students under use the resources available to them and instead rely on instructors for information.

The training in clinical techniques and the use of clinical veterinary equipment was cited by students in this study as building their confidence and thus aiding feelings of readiness for clinical studies and placements. This was supported by $77 \%$ of respondents agreeing that their teaching had helped them on clinical placements and this may explain the overwhelmingly positive response to the statements that anatomy is an important subject in the veterinary curriculum and important for practice. The students recognise the importance of the subject, however, that does not necessarily mean they are motivated to learn it. In the study of Dutch medical students it was concluded that junior medical students were more likely to judge how important it is to study a subject based on how heavily it is assessed rather than how relevant the subject is to their career. [46] Drivers for learning such as assessment and instructor expectations feature in comments made by students in second year and in fourth year at SVMS, indicating an extrinsic motivation that persists throughout the course. However, comments received by fourth year students describe a desire to become a good vet, reflecting a change to an intrinsic motivation for learning as undergraduates progress through the course.

Retrospectively fourth year students felt dissection and prosection were less valuable in relation to assessment than they believed the methods to be in second year. This result is perhaps unsurprising since students spend a limited amount of hours in the dissection laboratory in year three and thus are not examined on anatomical concepts in this year of the course. At the time this survey was carried out fourth year assessments had not begun. It is not the remit of this paper to consider assessment in relation to student attitudes, thus further work should be conducted in this area to evaluate the impact of assessment on learning anatomy.

\section{Limitations}

This study captures the perceptions of one cohort of students studying at one vet school in the UK and so caution should be applied to generalisations. Similarly, the questionnaire investigates perceptions at one moment in time after a practical class which will likely bias opinion based on the module under study at the time of administration. Response rates for paired analysis were limited by students' attendance in practical classes and a flux of students into and out of year groups. It is accepted that further information could have been garnered by distinguishing 'interesting' from 'motivating' in the questionnaire and subsequent analysis. Finally, alpha values were below 0.7 in some domains and as such summed data should be interpreted with caution.

\section{Conclusions}

This study has highlighted the value of cadaver practical classes throughout the veterinary undergraduate course. The introduction of clinical skills within the anatomy curriculum has a positive impact on students' perceptions of learning anatomy, with learners appreciating the relevance of the material covered in these sessions from preclinical to clinical years. Anatomy as a subject is mostly knowledge based, but its application to practice is significant and can be taught through the introduction of clinical techniques early in the curriculum, allowing factual information to be contextualised and consolidated. It is suggested therefore that anatomy continues to be delivered using cadaver materials using a combination of traditional methods and clinical teaching. Moreover, it is believed that further investigation into perceptions of multiple cohorts of 
443

444

445

446

447

448

449

450

451

452

453

454

455

456

457

458

459

460

461

462

463

464

465

466

467

468

469

470

471

472

473

474

475

476

477

478

479

480

481

482

483

484

485

486

487

488

489

490

491

492

493

494

495

496

497

498

499

students and the educational outcomes of anatomy teaching can further inform the veterinary anatomy curriculum.

1. Waterston, S. and I. Stewart, Survey of clinicians' attitudes to the anatomical teaching and knowledge of medical students. Clinical Anatomy, 2005. 18(5): p. 380-384.

2. Fitzgerald, J., et al., Are we teaching sufficient anatomy at medical school? The opinions of newly qualified doctors. Clin Anat, 2008. 21(7): p. 718-724.

3. Leveritt, S., et al., What anatomy is clinically useful and when should we be teaching it? Anatomical Sciences Education, 2016: p. n/a-n/a.

4. Azer, S.A. and N. Eizenberg, Do we need dissection in an integrated problembased learning medical course? Perceptions of first-and second-year students. Surgical and Radiologic Anatomy, 2007. 29(2): p. 173-180.

5. Bergman, E.M., et al., How much anatomy is enough? Anatomical Sciences Education, 2008. 1(4): p. 184-188.

6. Patel, K.M. and B.J. Moxham, The relationships between learning outcomes and methods of teaching anatomy as perceived by professional anatomists. Clinical Anatomy, 2008. 21(2): p. 182-189.

7. Theoret, C.L., E.N. Carmel, and S. Bernier, Why dissection videos should not replace cadaver prosections in the gross veterinary anatomy curriculum: results from a comparative study. J Vet Med Educ, 2007. 34(2): p. 151-6.

8. Cake, M.A., Deep dissection: motivating students beyond rote learning in veterinary anatomy. J Vet Med Educ, 2006. 33(2): p. 266-71.

9. Winkelmann, A., Anatomical dissection as a teaching method in medical school: a review of the evidence. Medical Education, 2007. 41(1): p. 15-22.

10. Heylings, D.J., Anatomy 1999-2000: the curriculum, who teaches it and how? 2002(0308-0110 (Print)).

11. Drake, R.L., et al., Medical education in the anatomical sciences: The winds of change continue to blow. Anatomical Sciences Education, 2009. 2(6): p. 253-259.

12. Ryan, M.T., et al., Practical classes: a platform for deep learning? Overall context in the first-year veterinary curriculum. J Vet Med Educ, 2009. 36(2): p. 180-5.

13. Böckers, A., et al., The gross anatomy course: An analysis of its importance. Anatomical Sciences Education, 2010. 3(1): p. 3-11.

14. Dinsmore, C.E., S. Daugherty, and H.J. Zeitz, Teaching and learning gross anatomy: Dissection, prosection, or "both of the above?". Clinical Anatomy, 1999. 12(2): p. 110-114.

15. Nnodim, J.O., Learning human anatomy: by dissection or from prosections? Medical Education, 1990. 24(4): p. 389-395.

16. Scott, T., How we teach anatomy efficiently and effectively. Medical teacher, 1993. 15(1): p. 67-75.

17. McLachlan, J.C., New path for teaching anatomy: Living anatomy and medical imaging vs. dissection. The Anatomical Record Part B: The New Anatomist, 2004. 281B(1): p. 4-5.

18. McLachlan, J.C. and D. Patten, Anatomy teaching: ghosts of the past, present and future. Medical Education, 2006. 40(3): p. 243-253.

19. Brown, B., et al., Introduction of ultrasound into gross anatomy curriculum: perceptions of medical students. J Emerg Med, 2012. 43(6): p. 1098-102.

20. Ivanusic, J., B. Cowie, and M. Barrington, Undergraduate student perceptions of the use of ultrasonography in the study of "Living Anatomy". Anatomical Sciences Education, 2010. 3(6): p. 318-322.

21. Fitzpatrick, C.M., G.L. Kolesari, and K.J. Brasel, Teaching anatomy with surgeons' tools: Use of the laparoscope in clinical anatomy. Clinical Anatomy, 2001. 14(5): p. 349-353.

22. General Medical Council. Tomorrow's Doctors. 1993; Available from: http://www.gmc-uk.org/Tomorrows Doctors 1993.pdf 25397206.pdf.

23. Older, J., Anatomy: A must for teaching the next generation. The Surgeon, 2004. 2(2): p. 79-90. 
24. Bergman, E., C.P. Van Der Vleuten, and A.J. Scherpbier, Why don't they know enough about anatomy? A narrative review. Medical teacher, 2011. 33(5): p. 403-409.

25. RCVS. RCVS Day One Competences. 2014; Available from: http://www.rcvs.org.uk/document-library/rcvs-day-one-competences.

26. Salazar, I., Coming Changes in Veterinary Anatomy: What Is or Should Be Expected? Journal of Veterinary Medical Education, 2002. 29(3): p. 126-130.

27. Ginneken, C.J.V. and G. Vanthournout, Rethinking the Learning and Evaluation Environment of a Veterinary Course in Gross Anatomy: The Implementation of an Assessment and Development Center and an E-Learning Platform. Journal of Veterinary Medical Education, 2005. 32(4): p. 537-543.

28. Doherty, M.L. and B.R. Jones, Undergraduate Veterinary Education at University College Dublin: A Time of Change. Journal of Veterinary Medical Education, 2006. 33(2): p. 214-219.

29. Kinnison, T., et al., Teaching bovine abdominal anatomy: Use of a haptic simulator. Anatomical Sciences Education, 2009. 2(6): p. 280-285.

30. Nemanic, S., et al., The Effectiveness of a 3D Computerized Tutorial to Enhance Learning of the Canine Larynx and Hyoid Apparatus. Journal of Veterinary Medical Education, 2016. 43(3): p. 243-254.

31. Latorre, R.M., et al., How Useful Is Plastination in Learning Anatomy? Journal of Veterinary Medical Education, 2007. 34(2): p. 172-176.

32. Braid, F., S.B. Williams, and R. Weller, Design and validation of a novel learning tool, the "Anato-Rug," for teaching equine topographical anatomy. Anatomical Sciences Education, 2012. 5(5): p. 256-263.

33. Harden, R.M., What is a spiral curriculum? Medical Teacher, 1999. 21(2): p. 141143.

34. Braun, V. and V. Clarke, Using thematic analysis in psychology. Qualitative Research in Psychology, 2006. 3(2): p. 77-101.

35. Patton, M.Q., Enhancing the quality and credibility of qualitative analysis. Health services research, 1999. 34(5 Pt 2): p. 1189.

36. Dangerfield, P., P. Bradley, and T. Gibbs, Learning gross anatomy in a clinical skills course. Clinical Anatomy, 2000. 13(6): p. 444-447.

37. Davis, C.R., et al., Human anatomy: let the students tell us how to teach. Anat Sci Educ, 2014. 7(4): p. 262-72.

38. Fransson, A., ON QUALITATIVE DIFFERENCES IN LEARNING: IV-EFFECTS OF INTRINSIC MOTIVATION AND EXTRINSIC TEST ANXIETY ON PROCESS AND OUTCOME. British Journal of Educational Psychology, 1977. 47(3): p. 244-257.

39. Parkinson, T.J., M. Gilling, and G.T. Suddaby, Workload, study methods, and motivation of students within a BVSc program. Journal of Veterinary Medical Education, 2006. 33(2): p. 253-265.

40. Mills, P., Group Project Work with Undergraduate Veterinary Science Students. Assessment \& Evaluation in Higher Education, 2003. 28(5): p. 527-538.

41. Anderson, J. and A. Graham, A problem in medical education: is there an information overload? Medical Education, 1980. 14(1): p. 4-7.

42. May, S.A., Modern veterinary graduates are outstanding, but can they get better? J Vet Med Educ, 2008. 35(4): p. 573-80.

43. Patel, S., Anatomy: Too much too soon at medical school. Clinical Anatomy, 2009. 22(2): p. 287-287.

44. Jamniczky, H.A., et al., Cognitive load imposed by knobology may adversely affect learners' perception of utility in using ultrasonography to learn physical examination skills, but not anatomy. Anatomical Sciences Education, 2015. 8(3): p. 197-204.

45. Heath, T.J., A. Lanyon, and M. Lynch-Blosse, A longitudinal study of veterinary students and recent graduates: 3. Perceptions of veterinary education. Australian Veterinary Journal, 1996. 74(4): p. 301-304. 
46. Bergman, E.M., et al., Students' perceptions of anatomy across the undergraduate problem-based learning medical curriculum: a phenomenographical study. BMC Medical Education, 2013. 13(1): p. 1-11.

47. Finn, G.M., D. Patten, and J.C. McLachlan, The impact of wearing scrubs on contextual learning. Medical Teacher, 2010. 32(5): p. 381-384.

48. Smith, C.F. and H.S. Mathias, Medical students' approaches to learning anatomy: Students' experiences and relations to the learning environment. Clinical Anatomy, 2010. 23(1): p. 106-114.

49. Ward, P.J., First year medical students' approaches to study and their outcomes in a gross anatomy course. Clinical Anatomy, 2011. 24(1): p. 120-127.

50. Murdoch-Eaton, D. and S. Whittle, Generic skills in medical education: developing the tools for successful lifelong learning. Medical Education, 2012. 46(1): p. 120128.

51. Hall, E.R., et al., Doing dissections differently: A structured, peer-assisted learning approach to maximizing learning in dissections. Anatomical Sciences Education, 2013. 6(1): p. 56-66.

\section{APPENDIX 1. Year 4 survey}

You may remember participating in a survey in $2^{\text {nd }}$ year in which you gave your opinions on learning with cadaver material. As a continuation of this, $I^{\prime} d$ really appreciate your time in completing the similar survey below. The recently published results of the AVS survey reported that Nottingham students rated practical classes very highly, and we want to make sure the classes remain valuable to you. Thank you for your participation so far.

I'm asking for your help again now that you are two years older (and hopefully wiser) as I'm interested to see how and if your perspective has changed. Therefore, please respond to the statements by marking the box that most reflects your experiences and feelings to the statements. Please add any comments not covered by the statements in the free text space at the end of each section.

Please note - for the purposes of this study:

'Dissection' is intended to mean the dissection of cadaver material carried out by the student either individually or in small groups

'Demonstration of prosections' refers to teaching whereby a demonstrator/lecturer will present material to the student in order to describe anatomy/physiology

'Practising clinical/practical techniques' denotes the use of cadaver material in performing practical veterinarian skills and includes such activities as ultrasound, endoscopy, suturing etc.

\section{Section 1 Gaining anatomical knowledge}

Thinking back to your year 1 and 2 practical classes please rate how strongly you agree or disagree with each of the following statements relating to how cadaver material aids in your understanding of anatomy by placing a tick $(\checkmark)$ in one of the boxes for each statement.

Dissection of cadaver material

\begin{tabular}{||l|c|c|c|c|c||}
\hline \hline & $\begin{array}{c}\text { Strongly } \\
\text { Agree } \\
1\end{array}$ & Agree & Neutral & Disagree & $\begin{array}{c}\text { Strongly } \\
\text { Disagree } \\
5\end{array}$ \\
\hline $\begin{array}{l}\text { Helped me to relate structure to } \\
\text { function }\end{array}$ & & 2 & 3 & 4 & \\
\hline $\begin{array}{l}\text { Helped me with 3D appreciation of } \\
\text { structures }\end{array}$ & & & & & \\
\hline $\begin{array}{l}\text { Improved my understanding of } \\
\text { anatomy }\end{array}$ & & & & \\
\hline
\end{tabular}

Demonstration of prosections

\begin{tabular}{||l|c|c|c|c|c||}
\hline \hline & $\begin{array}{c}\text { Strongly } \\
\text { Agree } \\
1\end{array}$ & Agree & Neutral & Disagree & $\begin{array}{c}\text { Strongly } \\
\text { Disagree } \\
5\end{array}$ \\
\hline $\begin{array}{l}\text { Helped me to relate structure to } \\
\text { function }\end{array}$ & & 2 & 3 & 4 & \\
\hline $\begin{array}{l}\text { Helped me with 3D appreciation of } \\
\text { structures }\end{array}$ & & & & & \\
\hline $\begin{array}{l}\text { Improved my understanding of } \\
\text { anatomy }\end{array}$ & & & & & \\
\hline
\end{tabular}

Practising clinical/practical techniques on cadaver material 


\section{Section 2 Application of anatomical knowledge}

Thinking back to your year 1 and 2 practical classes, please rate how strongly you agree or disagree with each of the following statements relating to the application of knowledge to veterinary skills using cadaver material by placing a tick $(\checkmark)$ in one of the boxes for each statement.

\section{Dissection of cadaver material}

\begin{tabular}{||l|c|c|c|c|c||}
\hline \hline & $\begin{array}{c}\text { Strongly } \\
\text { Agree } \\
1\end{array}$ & Agree & Neutral & Disagree & $\begin{array}{c}\text { Strongly } \\
\text { Disagree } \\
5\end{array}$ \\
\hline $\begin{array}{l}\text { Opportunity to put theory into } \\
\text { practice }\end{array}$ & & 2 & 3 & 4 & \\
\hline Is relevant to my career & & & & & \\
\hline
\end{tabular}

\section{Demonstration of prosections}

\begin{tabular}{||l|c|c|c|c|c||}
\hline \hline & $\begin{array}{c}\text { Strongly } \\
\text { Agree } \\
1\end{array}$ & Agree & Neutral & Disagree & $\begin{array}{c}\text { Strongly } \\
\text { Disagree } \\
5\end{array}$ \\
\hline $\begin{array}{l}\text { Opportunity to put theory into } \\
\text { practice }\end{array}$ & & 2 & 3 & 4 & \\
\hline Is relevant to my career & & & & & \\
\hline
\end{tabular}

Practising clinical/practical techniques on cadaver material

\begin{tabular}{||l|c|c|c|c|c||}
\hline \hline & $\begin{array}{c}\text { Strongly } \\
\text { Agree } \\
1\end{array}$ & Agree & Neutral & Disagree & $\begin{array}{c}\text { Strongly } \\
\text { Disagree } \\
5\end{array}$ \\
\hline $\begin{array}{l}\text { Opportunity to put theory into } \\
\text { practice }\end{array}$ & & 2 & 3 & 4 & \\
\hline Is relevant to my career & & & & & \\
\hline
\end{tabular}

Do you have any other comments regarding application of knowledge using cadaver material?

\section{Section 3 Enjoyment}

Thinking back to your year 1 and 2 practical classes, please rate how strongly you agree or disagree with each of the following statements relating to enjoyment of classes using cadaver material by placing a tick $(\checkmark)$ in one of the boxes for each statement.

\begin{tabular}{l} 
Dissection of cadaver material \\
\hline \hline
\end{tabular} \begin{tabular}{c|c|c|c|c|c|}
$\begin{array}{c}\text { Strongly } \\
\text { Agree } \\
1\end{array}$ & $\begin{array}{c}\text { Agree } \\
\text { I found it interesting/motivating }\end{array}$ & 2 & 3 & 4 & $\begin{array}{c}\text { Disagree } \\
\text { Disagree } \\
5\end{array}$ \\
\hline $\begin{array}{l}\text { I found it to be a negative } \\
\text { experience }\end{array}$ & & & & & \\
\hline $\begin{array}{l}\text { Please comment as to what made } \\
\text { the experience negative }\end{array}$ & & & & \\
\hline
\end{tabular}




\begin{tabular}{|l|c|c|c|c|c|}
\hline & $\begin{array}{c}\text { Strongly } \\
\text { Agree } \\
1\end{array}$ & Agree & Neutral & Disagree & $\begin{array}{c}\text { Strongly } \\
\text { Disagree } \\
5\end{array}$ \\
\hline I found it interesting/motivating & & 2 & 3 & & \\
\hline $\begin{array}{l}\text { I found it to be a negative } \\
\text { experience }\end{array}$ & & & & & \\
\hline $\begin{array}{l}\text { Please comment as to what made } \\
\text { the experience negative }\end{array}$ & \multicolumn{3}{|l}{} \\
\hline
\end{tabular}

\begin{tabular}{|c|c|c|c|c|c|}
\hline 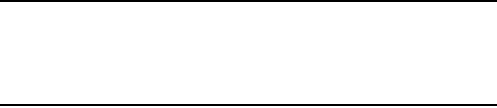 & $\begin{array}{c}\text { Strongly } \\
\text { Agree } \\
1\end{array}$ & $\begin{array}{c}\text { Agree } \\
2 \\
\end{array}$ & $\begin{array}{c}\text { Neutral } \\
3 \\
\end{array}$ & $\begin{array}{c}\text { Disagree } \\
4 \\
\end{array}$ & $\begin{array}{c}\text { Strongly } \\
\text { Disagree } \\
5\end{array}$ \\
\hline \multicolumn{6}{|l|}{ I found it interesting/motivating } \\
\hline \multicolumn{6}{|l|}{$\begin{array}{l}\text { I found it to be a negative } \\
\text { experience }\end{array}$} \\
\hline $\begin{array}{l}\text { Please comment as to what made } \\
\text { the experience negative }\end{array}$ & & & & & \\
\hline
\end{tabular}

Do you have any other comments regarding your enjoyment of sessions utilising cadaver material?

\section{Section 4 Assessment}

Thinking back to your year 1 and 2 practical classes, please rate how strongly you agree or disagree with each of the following statements relating to assessment by placing a tick $(\checkmark)$ in one of the boxes for each statement.

\begin{tabular}{|c|c|c|c|c|c|}
\hline & $\begin{array}{c}\text { Strongly } \\
\text { Agree } \\
1\end{array}$ & $\begin{array}{c}\text { Agree } \\
2 \\
\end{array}$ & $\begin{array}{c}\text { Neutral } \\
3 \\
\end{array}$ & $\begin{array}{c}\text { Disagree } \\
4 \\
\end{array}$ & $\begin{array}{c}\text { Strongly } \\
\text { Disagree } \\
5\end{array}$ \\
\hline $\begin{array}{l}\text { It is important because it is assessed } \\
\text { in exams }\end{array}$ & & & & & \\
\hline $\begin{array}{l}\text { I found it useful preparation for } \\
\text { exams }\end{array}$ & & & & & \\
\hline
\end{tabular}

\section{Demonstration of prosections}

\begin{tabular}{||l|c|c|c|c|c||}
\hline \hline & $\begin{array}{c}\text { Strongly } \\
\text { Agree } \\
1\end{array}$ & Agree & Neutral & Disagree & $\begin{array}{c}\text { Strongly } \\
\text { Disagree } \\
5\end{array}$ \\
\hline $\begin{array}{l}\text { It is important because it is assessed } \\
\text { in exams }\end{array}$ & & 2 & 3 & 4 & \\
\hline $\begin{array}{l}\text { I found it useful preparation for } \\
\text { exams }\end{array}$ & & & & & \\
\hline
\end{tabular}

Practising clinical/practical techniques

\begin{tabular}{||l|c|c|c|c|c||}
\hline \hline & $\begin{array}{c}\text { Strongly } \\
\text { Agree } \\
1\end{array}$ & Agree & Neutral & Disagree & $\begin{array}{c}\text { Strongly } \\
\text { Disagree } \\
5\end{array}$ \\
\hline $\begin{array}{l}\text { It is important because it is assessed } \\
\text { in exams }\end{array}$ & & 2 & 3 & 4 & \\
\hline $\begin{array}{l}\text { I found it useful preparation for } \\
\text { exams }\end{array}$ & & & & & \\
\hline
\end{tabular}

Do you have any other comments regarding assessment?

\section{Section $5 \quad$ Learning process}

Thinking back to your year 1 and 2 practical classes, please rate how strongly you agree or disagree with each of the following statements relating to the learning process by placing a tick $(\checkmark)$ in one of the boxes for each statement.

Dissection of cadaver material 


\begin{tabular}{||l|c|c|c|c|c||}
\hline \hline & $\begin{array}{c}\text { Strongly } \\
\text { Agree } \\
1\end{array}$ & Agree & Neutral & Disagree & $\begin{array}{c}\text { Strongly } \\
\text { Disagree } \\
5\end{array}$ \\
\hline It relates to other teaching sessions & & 2 & 3 & 4 & \\
\hline It promotes peer learning & & & & & \\
\hline $\begin{array}{l}\text { It provides the opportunity to } \\
\text { participate and ask questions }\end{array}$ & & & & & \\
\hline $\begin{array}{l}\text { It encourages respect for the } \\
\text { material }\end{array}$ & & & & & \\
\hline
\end{tabular}

\section{Demonstration of prosections}

\begin{tabular}{||l|c|c|c|c|c||}
\hline \hline & $\begin{array}{c}\text { Strongly } \\
\text { Agree } \\
1\end{array}$ & Agree & Neutral & Disagree & $\begin{array}{c}\text { Strongly } \\
\text { Disagree } \\
5\end{array}$ \\
\hline It relates to other teaching sessions & & 2 & 3 & 4 & \\
\hline It promotes peer learning & & & & & \\
\hline $\begin{array}{l}\text { It provides the opportunity to } \\
\text { participate and ask questions }\end{array}$ & & & & & \\
\hline $\begin{array}{l}\text { It encourages respect for the } \\
\text { material }\end{array}$ & & & & & \\
\hline
\end{tabular}

\section{Practising clinical/practical techniques}

\begin{tabular}{|c|c|c|c|c|c|}
\hline " & $\begin{array}{c}\text { Strongly } \\
\text { Agree } \\
1\end{array}$ & $\begin{array}{c}\text { Agree } \\
2\end{array}$ & $\begin{array}{c}\text { Neutral } \\
3\end{array}$ & $\begin{array}{c}\text { Disagree } \\
4\end{array}$ & $\begin{array}{c}\text { Strongly } \\
\text { Disagree } \\
5\end{array}$ \\
\hline \multicolumn{6}{|l|}{ It relates to other teaching sessions } \\
\hline \multicolumn{6}{|l|}{ It promotes peer learning } \\
\hline \multicolumn{6}{|l|}{$\begin{array}{l}\text { It provides the opportunity to } \\
\text { participate and ask questions }\end{array}$} \\
\hline $\begin{array}{l}\text { It encourages respect for the } \\
\text { material }\end{array}$ & & & & & \\
\hline
\end{tabular}

Do you have any other comments regarding the learning process relating to cadaver material?

\section{Section $6 \quad$ Year 4 teaching}

Thinking about your current studies, please rate how strongly you agree or disagree with each of the following statements by placing a tick $(\checkmark)$ in one of the boxes for each statement.

\begin{tabular}{||l|c|c|c|c|c||}
\hline & $\begin{array}{c}\text { Strongly } \\
\text { Agree } \\
1\end{array}$ & Agree & Neutral & Disagree & $\begin{array}{c}\text { Strongly } \\
\text { Disagree } \\
5\end{array}$ \\
\hline $\begin{array}{l}\text { I think anatomy is an important part } \\
\text { of the veterinary curriculum }\end{array}$ & & 2 & 3 & 4 & \\
\hline $\begin{array}{l}\text { I have forgotten most of the } \\
\text { anatomy I learnt in the first two } \\
\text { years of the course }\end{array}$ & & & & & \\
\hline $\begin{array}{l}\text { We re-visit anatomy in our year } 4 \\
\text { teaching }\end{array}$ & & & & & \\
\hline $\begin{array}{l}\text { I have found the classes to be } \\
\text { relevant to CEMS }\end{array}$ & & & & & \\
\hline $\begin{array}{l}\text { I have not needed anatomical } \\
\text { knowledge in year } 4\end{array}$ & & & & & \\
\hline \hline
\end{tabular}

Do you have any other comments regarding anatomy in year 4 of the curriculum?

\section{Section 7 Beyond graduation}

Thinking about your future role as a clinician, please rate how strongly you agree or disagree with each of the following statements by placing a tick $(\checkmark)$ in one of the boxes for each statement.

\begin{tabular}{|l|c|c|c|c|c||}
\hline & $\begin{array}{c}\text { Strongly } \\
\text { Agree } \\
1\end{array}$ & Agree & Neutral & Disagree & $\begin{array}{c}\text { Strongly } \\
\text { Disagree } \\
5\end{array}$ \\
\hline
\end{tabular}


682

683

684

685

686

687

688

689

690

691 692

693

\begin{tabular}{||l|l|l|l|l|l||}
\hline $\begin{array}{l}\text { I think that good anatomical } \\
\text { knowledge will be important in } \\
\text { practice }\end{array}$ & & & & & \\
\hline $\begin{array}{l}\text { I feel confident my knowledge of } \\
\text { anatomy is sufficient for a job in } \\
\text { practice }\end{array}$ & & & & & \\
\hline $\begin{array}{l}\text { I expect to look up anatomical } \\
\text { information as and when I need it }\end{array}$ & & & & & \\
\hline
\end{tabular}

Do you have any other comments regarding anatomy beyond graduation?

\section{Tables}

\begin{tabular}{|l|l|l|}
\hline & Domain & Alpha score \\
\hline Questions 1-3 & $\begin{array}{l}\text { Gaining anatomical } \\
\text { knowledge }\end{array}$ & .829 \\
\hline Questions 4-5 & $\begin{array}{l}\text { Application of } \\
\text { knowledge }\end{array}$ & .742 \\
\hline Questions 6-7 & Enjoyment & .705 \\
\hline Questions 8-9 & Assessment & .910 \\
\hline Questions 10-13 & Learning process & .866 \\
\hline
\end{tabular}

Table 1. Internal consistency of items within an area of learning by year group

\begin{tabular}{lccccccc}
\hline \multicolumn{1}{c}{ Questions } & Method & $\begin{array}{c}\text { Strongly } \\
\text { Agree } \\
(\%)\end{array}$ & $\begin{array}{c}\text { Agree } \\
(\mathbf{\%})\end{array}$ & $\begin{array}{c}\text { Neutral } \\
\mathbf{( \% )}\end{array}$ & $\begin{array}{c}\text { Disagree } \\
(\mathbf{\%})\end{array}$ & $\begin{array}{c}\text { Strongly } \\
\text { Disagree } \\
(\mathbf{\%})\end{array}$ & $\begin{array}{c}\text { Mean } \\
\text { score }\end{array}$ \\
\hline 1. Helps me relate & $\mathrm{D}$ & 53 & 39 & 5 & 3 & 0 & 1.6 \\
structure to & $\mathrm{P}$ & 44 & 44 & 10 & 2 & 0 & 1.7 \\
function & $\mathrm{T}$ & 64 & 31 & 3 & 0 & 2 & 1.4 \\
2. Aids in 3D & $\mathrm{D}$ & 71 & 28 & 2 & 0 & 0 & 1.3 \\
appreciation of & $\mathrm{P}$ & 54 & 34 & 12 & 0 & 0 & 1.6 \\
structures & $\mathrm{T}$ & 66 & 30 & 5 & 0 & 0 & 1.4 \\
3. Improves my & $\mathrm{D}$ & 61 & 38 & 2 & 0 & 0 & 1.4 \\
understanding & $\mathrm{P}$ & 67 & 30 & 3 & 0 & 0 & 1.4 \\
& $\mathrm{~T}$ & 66 & 26 & 8 & 0 & 0 & 1.4 \\
4. Provides an & $\mathrm{D}$ & 49 & 46 & 5 & 0 & 0 & 1.6 \\
opportunity to put & $\mathrm{P}$ & 33 & 53 & 13 & 2 & 0 & 1.8 \\
theory into & $\mathrm{T}$ & 84 & 15 & 2 & 0 & 0 & 1.2 \\
practice & & & & & & & \\
5. Is relevant to & $\mathrm{D}$ & 64 & 33 & 3 & 0 & 0 & 1.4 \\
my career & $\mathrm{P}$ & 44 & 48 & 8 & 0 & 0 & 1.6 \\
& $\mathrm{~T}$ & 90 & 10 & 0 & 0 & 0 & 1.1 \\
6. I found it & $\mathrm{D}$ & 33 & 59 & 7 & 2 & 0 & 1.8 \\
interesting/motiva & $\mathrm{P}$ & 38 & 53 & 8 & 2 & 0 & 1.7 \\
ting & $\mathrm{T}$ & 89 & 12 & 0 & 0 & 0 & 1.1 \\
7. I found it to be & $\mathrm{D}$ & 0 & 5 & 4 & 45 & 47 & 4.3 \\
a negative & $\mathrm{P}$ & 0 & 2 & 7 & 44 & 48 & 4.4 \\
experience & $\mathrm{T}$ & 2 & 2 & 2 & 19 & 76 & 4.7 \\
8. It is important & $\mathrm{D}$ & 57 & 39 & 3 & 0 & 0 & 1.5 \\
because it is & $\mathrm{P}$ & 57 & 36 & 7 & 0 & 0 & 1.5 \\
assessed in & $\mathrm{T}$ & 59 & 31 & 7 & 3 & 0 & 1.5 \\
exams & & & & & & & \\
& & & & & & &
\end{tabular}




$\begin{array}{llllllll}\text { 9. I found it useful } & \mathrm{D} & 46 & 46 & 8 & 0 & 0 & 1.6 \\ \text { preparation for } & \mathrm{P} & 51 & 43 & 3 & 2 & 2 & 1.6 \\ \text { exams } & \mathrm{T} & 69 & 26 & 3 & 2 & 0 & 1.4 \\ \text { 10. It relates to } & \mathrm{D} & 48 & 53 & 0 & 0 & 0 & 1.5 \\ \text { other teaching } & \mathrm{P} & 49 & 46 & 5 & 0 & 0 & 1.6 \\ \text { sessions } & \mathrm{T} & 66 & 33 & 2 & 0 & 0 & 1.4 \\ \text { 11. It promotes } & \mathrm{D} & 41 & 48 & 10 & 2 & 0 & 1.7 \\ \text { peer learning } & \mathrm{P} & 20 & 39 & 33 & 7 & 2 & 2.3 \\ & \mathrm{~T} & 44 & 46 & 10 & 0 & 0 & 1.7 \\ \text { 12. It provides } & \mathrm{D} & 45 & 40 & 15 & 0 & 0 & 1.7 \\ \text { the opportunity to } & \mathrm{P} & 51 & 36 & 13 & 0 & 0 & 1.6 \\ \text { ask questions } & \mathrm{T} & 56 & 38 & 7 & 0 & 0 & 1.5 \\ \text { 13. It encourages } & \mathrm{D} & 23 & 47 & 27 & 3 & 0 & 2.1 \\ \text { respect for the } & \mathrm{P} & 18 & 56 & 21 & 5 & 0 & 2.1 \\ \text { material } & \mathrm{T} & 34 & 41 & 23 & 2 & 0 & 1.9\end{array}$

Table 2. Results of year 2 questionnaire.

Values are expressed as a percentage of total student responses recorded on a 5 point Likert scale $(1=$ Strongly agree; 5 = strongly disagree) thus lower sores indicate a higher value.

$D$ refers to dissection activities; $P$, prosection and $T$, practising techniques.

Percentages may not sum to 100 due to rounding.

\begin{tabular}{lccccc}
\hline Teaching & \multicolumn{5}{c}{ Mean ranks by area of learning } \\
method & Knowledge & Application & Enjoyment & Assessment & Learning \\
\hline Dissection & 2.0 & 2.1 & 2.3 & 2.1 & 2.1 \\
Prosection & 2.2 & 2.4 & 2.2 & 2.1 & 2.3 \\
Techniques & 1.9 & 1.5 & 1.5 & 1.8 & 1.6
\end{tabular}

Table 3. Mean rank scores for dissection, prosection, and practising techniques by area of learning. ( $1=$

\begin{tabular}{|c|c|c|}
\hline $\begin{array}{l}\text { Theme } \\
\text { (year of study) }\end{array}$ & Definition & Example comment \\
\hline $\begin{array}{l}\text { Positive impact } \\
\text { (yr2 and yr4) }\end{array}$ & $\begin{array}{l}\text { Positive comments } \\
\text { reflecting enjoyment of } \\
\text { practicals. Classes are } \\
\text { useful or helpful to learning }\end{array}$ & $\begin{array}{l}\text { "Couldn't pass Vet School } \\
\text { without them. Makes } \\
\text { lectures actually make } \\
\text { sense." - Yr2 }\end{array}$ \\
\hline $\begin{array}{l}\text { Barriers to learning } \\
\text { (yr2 and yr4) }\end{array}$ & $\begin{array}{l}\text { Negative aspects of classes } \\
\text { that students feel hinder } \\
\text { learning. Barriers include } \\
\text { large group sizes, poor } \\
\text { quality or validity of } \\
\text { specimens, bad smells and } \\
\text { difficulty of tasks }\end{array}$ & $\begin{array}{l}\text { "When techniques have to } \\
\text { be altered for cadaver } \\
\text { material" - Yr2 }\end{array}$ \\
\hline $\begin{array}{l}\text { Student/teacher balance } \\
\text { (yr2 and yr4) }\end{array}$ & $\begin{array}{l}\text { Demonstrates student } \\
\text { preferences for either } \\
\text { student-led learning } \\
\text { techniques, teacher-led } \\
\text { techniques or a balance } \\
\text { between the two. Year } 4 \\
\text { comments include those } \\
\text { expressing a need to re- } \\
\text { visit anatomical topics }\end{array}$ & $\begin{array}{l}\text { "More time should be spent } \\
\text { on demonstration before } \\
\text { dissection as otherwise we } \\
\text { don't know what we're } \\
\text { looking for" - Yr4 }\end{array}$ \\
\hline
\end{tabular}




\begin{tabular}{|c|c|c|}
\hline $\begin{array}{l}\text { Respect } \\
\text { (yr2 and yr4) }\end{array}$ & $\begin{array}{l}\text { Concerns regarding a lack } \\
\text { of respect towards } \\
\text { cadaveric material }\end{array}$ & $\begin{array}{l}\text { "There should be more } \\
\text { emphasis on respect for } \\
\text { dissection material" - Yr2 }\end{array}$ \\
\hline $\begin{array}{l}\text { Relevance } \\
\text { (yr4) }\end{array}$ & $\begin{array}{l}\text { The positive impact of an } \\
\text { activity's relevance }\end{array}$ & $\begin{array}{l}\text { "Much more enjoyable } \\
\text { when made clinically } \\
\text { relevant and practising } \\
\text { actual techniques that } \\
\text { would be used on live } \\
\text { animals" - Yr4 }\end{array}$ \\
\hline $\begin{array}{l}\text { Transition to clinical } \\
\text { studies } \\
\text { (yr4) }\end{array}$ & $\begin{array}{l}\text { The change in motivation } \\
\text { for learning }\end{array}$ & $\begin{array}{l}\text { "Earlier in the course I } \\
\text { think it is more about } \\
\text { exams but now it is about } \\
\text { learning to do it to become } \\
\text { a good vet" - Yr4 }\end{array}$ \\
\hline
\end{tabular}

Table 4. Themes arising from free text responses

\section{Figure Captions}

Figure 1. Relative frequencies of positive responses by year of study, all students

$D$ refers to dissection activities; $P$, prosection and $T$, practising techniques.

Counts for strongly agree and agree were summed for each question within a domain and presented as a percentage of overall response for that domain

Figure 2. Responses regarding year 4 teaching

Figure 3. Year 4 student responses regarding post-graduation expectations 